\title{
PENGARUH EKSTRAK DAUN TURI MERAH TERHADAP KOLONI BAKTERI PADA MENCIT NIFAS
}

\author{
Tut Rayani Aksohini Wijayanti \\ Politeknik Kesehatan RS dr. Soepraoen \\ Email: tutrayani@gmail.com
}

\begin{abstract}
Abstrak
Kejadian infeksi sering terjadi pada saat masa nifas yang dipicu oleh adanya perlukaan pada organ reproduksi. Hal ini memicu munculnya bakteri pathogen melalui jalan lahir seperti Streptococcus agalactiae. Turi (Sesbania grandiflora) merupakan tanaman yang sangat mudah tumbuh sering dimanfaatkan dalam pengobatan karena memiliki kandungan kimia seperti flovonoid, saponin, tanin, karbohidrat, phytosterol, triterpenes. Metode penelitian menggunakan true experiment posttest only control group design. Replikasi penelitian mencit sebanyak 28 ekor dan dikelompokkan menjadi 4 yaitu kontrol, kelompok P1, kelompok P2 dan kelompok P3. Pengukuran koloni bakteri dilakukan dengan menggunakan metode Pour Plate. Hasil analisis secara keseluruhan menunjukkan pemberian ekstrak daun turi merah mampu menurunkan koloni bakteri pada mencit nifas. Pemberian ekstrak daun turi merah pada mencit nifas tidak berpengaruh signifikan menurunkan koloni bakteri. Oleh karena itu ekstrak daun turi merah dapat bermanfaat untuk meningkatkan imunitas tubuh agar tidak terjadi infeksi pada masa nifas berlangsung.
\end{abstract}

Kata kunci : Ekstrak daun turi merah, Koloni Bakteri

\begin{abstract}
The incidence of infection often occurs during the puerperium period triggered by an injury to the reproductive organs. This triggers the emergence of pathogenic bacteria through the birth canal such as Streptococcus agalactiae. Turi (Sesbania grandiflora) is a very easy plant to grow often used in medicine because it has chemical content such as flovonoids, saponins, tannins, carbohydrates, phytosterol, triterpenes. The type of research method to be used is true experiment posttest only control group design. Research replication of 28 mice and grouped into 4, control, P1 group, group $P 2$ and group P3. The measurement of bacterial colonies was done using the Pour Plate method. The results of the analysis as a whole showed that the extract of red turi leaves was able to decrease the bacterial colonies in the puerperal mice. Provision of red turi leaf extract in puerperal mice did not significantly influence bacterial colonies. Therefore, red turi leaf extract can be useful to improve body immunity to avoid infection during childbirth period.
\end{abstract}

Keywords: red turi (Sesbania grandiflora)leaf extract, bacterial colonies

\section{PENDAHULUAN}

Kematian maternal merupakan kematian yang terjadi pada saat hamil, proses persalinan serta masa nifas yang berlangsung selama 42 hari. Menurut data SDKI, AKI pada tahun 2016 sebesar 309 per 100.000 kelahiran hidup. Data angka kematian ibu tersebut masih sangat besar dan jauh dari target SDGs (Sustainable Development Goals) yang ditargetkan sebesar 70 per 100.000 kelahiran hidup (Kementerian
Kesehatan RI, 2013).

Penyebab kematian maternal yang paling sering adalah perdarahan pasca persalinan (30,3\%), hipertensi $(27,1 \%)$ dan kejadian infeksi (7,3\%). Kejadian infeksi sering terjadi pada saat masa nifas yang dipicu oleh adanya perlukaan pada organ reproduksi. Hal ini memicu munculnya bakteri pathogen melalui jalan lahir (Kementerian Kesehatan RI, 2013).

Bakteri yang paling umum diisolasi pada 
Tut Rayani Aksohini W, Pengaruh Ekstrak Daun Turi...

infeksi nifas salah satunya yaitu Streptococcus agalactiae. Penggunaan antibiotik yang tidak sesuai dengan anjuran dokter akan mengakibatkan adanya mikroba yang mutan sehingga menjadi resisten terhadap berbagai antibiotic (Popescu, 2013). Dengan adanya resistensi bakteri mendorong dalam pencarian langkah alternatif dengan pemberian antibakteri berbahan alami.

Indonesia dikenal kaya akan bahan alam yang dapat digunakan sebagai pengobatan. Namun dalam penggunaannya harus diketahui terlebih dahulu potensi dari tanaman tersebut. Dalam penelitian Yusniawati (2015), menemukan bahwa ekstrak etanol daun turi merah memiliki efek antibakteri terhadap Staphylococcus aureus isolat 100-SV secara in vitro dengan KHM sebesar 14\%.

Turi (Sesbania grandiflora) merupakan tanaman yang sangat mudah tumbuh dan memiliki banyak manfaat (Yusuf \& Duwianta, 2012). Turi berbunga merah lebih sering dimanfaatkan dalam pengobatan dikarenakan memiliki kandungan kimia seperti flovonoid, saponin, tanin, karbohidrat, phytosterol, triterpenes, terpenoid pada turi merah lebih banyak daripada turi putih (Nasution dkk, 2010)

Berdasarkan penelitian Naqi (2014) bahwa dalam ekstrak daun Sesbania grandiflora terdapat kandungan kimia yaitu flavonoid, alkaloid, streroid, fenol, karbohidrat dan antrakuinon, serta tanin, saponin, terpenoids, dan pitosterol. Kandungan etanol dari Sesbania grandiflora dapat berfungsi sebagai antibakteri pada Streptococcus, Enterococcus faecalis (ATCC 29212), Staphylococcus aureus
(ATTCC 25923) dan bakteri gram negatif seperti Escherichia coli (ATCC 25922), Salmonella typhi (MTCC 733), Proteus vulgaris (MTCC 177).. Hal ini dapat digunakan sebagai acuan bahwa daun turi merah juga mempunyai efek antibakteri terhadap Streptococcus agalactiae.

\section{METODE PENELITIAN}

Mencit (Mus musculus), jenis kelamin betina, sehat, hamil dengan usia kehamilan 14 hari dan belum mendapat perlakuan. Dilakukan aklimatisasi selama 3 hari. Replikasi penilitian mencit sebanyak 28 ekor dikelompokkan menjadi 4 yaitu kontrol (Streptococcus agalactiae), kelompok P1 (Streptococcus agalactiae+ekstrak daun turi merah dosis 125 $\mathrm{mg} / \mathrm{kg} / \mathrm{BB}$ ), kelompok P2 (Streptococcus agalactiae+ekstrak daun turi merah dosis 250 $\mathrm{mg} / \mathrm{kg} / \mathrm{BB}$ ) dan kelompok P3 (Streptococcus agalactiae+ekstrak daun turi merah dosis 500 $\mathrm{mg} / \mathrm{kg} / \mathrm{BB})$.

Koloni bakteri Streptococcus agalactiae dihitung berdasarkan perubahan jumlah koloni bakteri pada vaginal lavage baik pada kelompok kontrol maupun kelompok perlakuan yang diperoleh setelah terminasi mencit postpartum 24 jam menggunakan metode Pour Plate dengan satuan CFU/ml. Skala yang digunakan adalah skala ratio. 


\section{HASIL PENELITIAN}

\section{Pengaruh turi merah (Sesbania grandiflora) terhadap koloni bakteri pada mencit nifas}
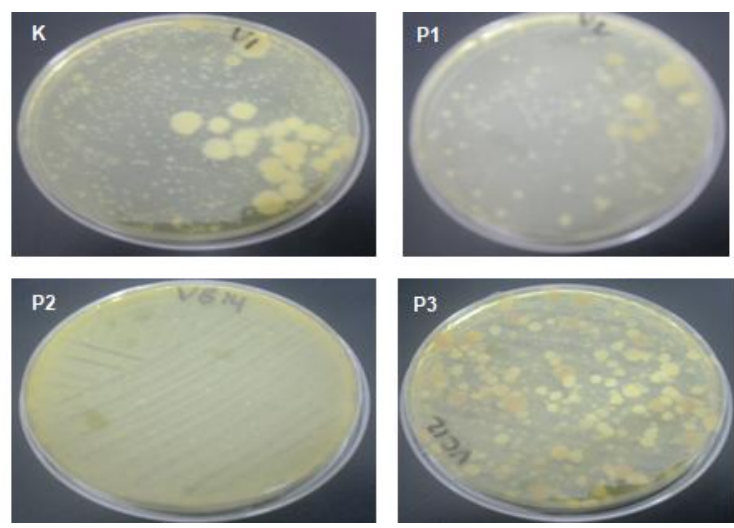

Gambar 1. Perbandingan koloni bakteri

Gambar 1 menunjukkan adanya perban dingan koloni bakteri pada kelompok kontrol, P1, P2 dan P3 yang ditandai dengan adanya warna kuning keemasan.

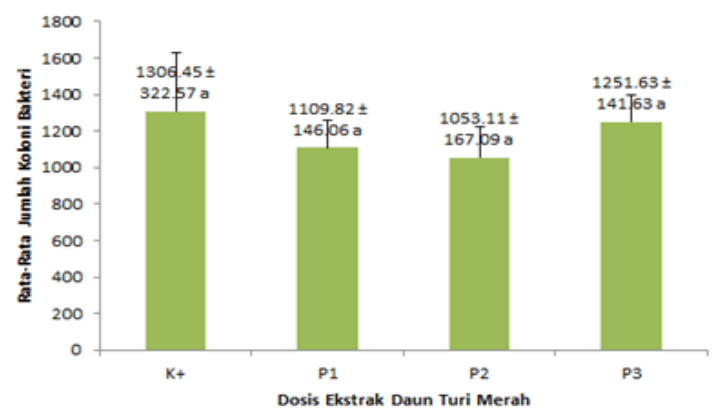

Berdasarkan analisis uji Kruskal-Willis, menunjukkan bahwa tidak terdapat perbedaan yang signifikan antara koloni bakteri pada mencit nifas kelompok kontrol dengan kelompok perlakuan. Hal ini ditunjukkan dengan adanya nilai $\mathrm{p}$-value $=0,217$ yang lebih besar daripada $\alpha=0,05(\mathrm{p}<0,05)$.

\section{PEMBAHASAN}

\section{Pengaruh turi merah (Sesbania grandiflora) terhadap koloni bakteri pada mencit nifas}

Berdasarkan grafik diatas menunjukkan koloni bakteri pada infeksi nifas mengalami penurunan. Didapatkan hasil uji ANOVA $p$ value sebesar 0.217, artinya bahwa p-value lebih besar daripada $\alpha=0,05$ ( $p>0,05)$. Sehingga dapat disimpulkan terjadi penurunan koloni bakteri namun tidak signifikan.

Dalam keadaan normal, pada vagina juga ditemukan Streptococcus hemolyticus group B, Streptococcus anaerob (Peptostrepto coccus), spesies Bacteroides, Clostridia, Gardnelia (Haemophillus) vaginalis, Ureaplasma urealyticum dan kadang-kadang Listeria atau spesies Mobilincus (Martin dkk, 2008; Curran, 2010; Preeti dkk, 2010). Flora normal merupakan flora yang sangat penting dalam pertahanan terhadap infeksi pada daerah genetalia. Jumlah flora normal dapat berubahubah selama kehidupan wanita. Perubahan pada flora normal ini akibat adanya perubahan hormon saat hamil sampai setelah melahirkan. Flora normal pada daerah genetalia memiliki peran sebagai mekanisme protektif host.

Streptococcus agalactiae merupakan salah satu flora normal yang terdapat pada vagina dengan jumlah sebesar 5-25\%. Mayoritas dari spesies ini akan tumbuh baik pada keadaan aerobik dan anaerob yang disebut sebagai "fakultatif anaerob" (Eschenbach, 2016; Madoff dkk, 2013). Saat pemeriksaan biasanya akan menunjukkan respons positif pada tes Christie, Atkins, Munch-Peterson (CAMP), hal ini merupakan efek dari hidrolisis natrium hipurat (Wijayani, 2008).

Dengan adanya kandungan flavonoid dari ekstrak daun turi merah yang diberikan secara oral maka akan berefek terhadap penurunan 
kolonisasi bakteri Streptococcus agalactiae pada infeksi nifas. Flavonoid akan membentuk senyawa kompleks yang terdapat pada protein ekstraseluler, hal ini yang menggangu integritas membran sel bakteri. Saponin berfungsi untuk mengganggu stabilitas membrane sel bakteri sehingga sel bakteri mengalami lisis dan tannin akan menyebabkan kerusakan pada dinding sel (Bryany, 2005).

Dalam Baratawidjaja dan Rengganis (2014) dijelaskan bahwa induksi respon imun oleh antigen tertentu di saluran cerna, dapat menyebarkan limfosit ke jaringan mukosa yang lain. Dalam penjelasan ini dapat disimpulkan bahwa dengan adanya pemberian ekstrak daun turi merah per oral dapat meningkatkan sistem imun yang berada di mukosa vagina.

Penelitian Erywiyatno (2012) dengan menggunakan madu selama 24 jam yang terdapat kandungan flavonoid, menunjukkan hasil adanya pengurangan jumlah koloni bakteri. Selain itu dalam penggunaan ekstrak kulit batang R. mucronata yang memiliki kandungan flavonoid, saponin dan tannin mampu menghambat pertumbuhan bakteri Streptococcus agalactiae (Pradana, 2012).

Pada penelitian ini dengan pemberian ekstrak daun turi merah per oral menunjukkan rerata jumlah koloni bakteri Streptococcus agalactiae pada kelompok mencit yang diberikan ekstrak daun turi merah mengalami penurunan dari dosis $125 \mathrm{mg} / \mathrm{kgBB}$ dan 250 $\mathrm{mg} / \mathrm{kgBB}$. Sedangkan pada kelompok mencit yang diberikan ekstrak daun turi merah dosis $500 \mathrm{mg} / \mathrm{kgBB}$ terlihat mengalami peningkatan dibandingkan dengan kelompok dosis lainnya.
Terjadinya peningkatan bakteri Streptococcus agalactiae ini karena bakteri bersifat apatogen serta telah mendapatkan kandungan zat aktif dari ekstrak daun turi merah. Dalam hal ini dapat dikatakan bahwa dengan pemberian ekstrak daun turi merah mampu menurunkan jumlah koloni bakteri Streptococcus agalactiae di mukosa vagina melalui adanya perubahan system imun berupa penurunan jumlah makrofag dan aktivasi NF-kB.

\section{KESIMPULAN}

Pemberian ekstrak daun turi merah (Sesbania grandiflora L. Pers) terbukti dapat menurunkan koloni bakteri pada mencit (Mus musculus) nifas.

\section{DAFTAR RUJUKAN}

Kementerian Kesehatan RI. 2013. Pusat Data dan Informasi Kementerian Kesehatan RI Mother's day. www.depkes.go.id, diakses 4 Februari 2016.

Popescu, F. 2013. Microbiological Study of Antepartum and Postpartum Vaginal Flora.

Yusniawati, E. 2015. Efek Antibakteri Ekstrak Etanol daun Turi Merah (Sesbania grandiflora L.Pers) terhadap Staphyloco ccus aureus Isolat 100-SV secara In Vitro. Tugas Akhir. Tidak diterbitkan, Fakultas Kedokteran Universitas Brawijaya, Malang.

Yusuf, H.,dan Duwianta. 2012. Informasi Singkat Benih; Sesbania grandiflora (L) Poiret. BPHT Sulawesi.

Nasution Ns, dkk. 2010. Keunggulan Turi sebagai pakan Ternak. Palembang: Ditjen 
Peternakan dan Keswan BPTU Sembawa.

Joshi, S. S., Dethe, U. I., Aparadh, V. T. 2014.

Screening of Bioactive of Sesbania grandiflora and Pistia stratiotes. Indian Journal of Advances in Plant Research (IJAPR). (I): 27-30.

Martin, R., Soberon, N., Vaneechoutte, M., Camino, F. V., Suarez, J. E., 2008. Characterization of Indigenous Vaginal Lactobacilli from Healthy Women as Probiotic Candidates. Journal of The Spanish Society for Microbiology, 11 (4): 261-266.

Curran, D. 2010. Bacterial Vaginosis. http://emedicine.medscape.com/article/254 342-overview. download on March, 05, 2016.

Preeti, N and Malani, M. D. mandell, Douglass and Bannett's Principles and Practice of Infectious Disease. The Journal of The American Medical. 2010, 304 (18): 20672071.

Eschenbach. 2016. A Multi Country Cross Sectional Study of Vaginal Carriage of Group B Streptococci.

Madoff, L. C., David, C. K., Nadeeza, I., Julie, C. D. H., Herve, T.., Kelly, R. S., Karen, M. P. 2013. The Two Component Response Regulator Liar Regulates Cell Wall Stress Responses, Pili Expression and Virulence in Group B Streptococcus. Microbiology; 159 (Pt 7): 1521-34. Epub.

Wijayani, C. 2008. Streptococcus agalactiae. Fakultas Farmasi Universitas Sumatra Utara. 